\title{
Change of Groundwater Flow Characteristics After Construction of the Waterworks System Protective Measures on the Danube River - A Case Study in Slovakia
}

\author{
František Burger \\ Slovak Academy of Sciences Institute of Hydrology \\ Slovak Republic
}

\section{Introduction}

The waterworks construction affects the hydrological regime of the flow of groundwater in the river alluvia that is usually in the hydrodynamic relation to the regime of the fluctuation of the surface watercourse level. To elaborate the prognosis of the changes in the regime of groundwater means to determine their sequence in time for the entire period of their creation until the final stable status is reached. It has to be made on the basis of the knowledge of hydrogeological situation within the territory and the contemporary regime of groundwater. The creation of such changes may be invoked by natural changes or also anthropogenic interventions into the water situation within the territory. The above implies this is the unsteady flow task from hydrodynamic point of view. It is natural since groundwater flow has always somehow the character of unsteady flow. It is implied by natural conditions of their supply and drainage. The regime of supply and drainage of groundwater in water-bearing collectors depends upon the factors not changed in time, so in general, the mode of fluctuation of groundwater level is affected by the changes in time as well and therefore it is unsteady. However, if the conditions of supply and drainage of groundwater are changed in time negligibly, or if the area of interest of the water-bearing collector is located in a certain sufficient distance from the source of supply and drainage point, the flow of groundwater may be practically considered to be stable. The time slope of the forecast changes within the determined area of flow then shall, in addition to other conditions, depend upon time changes in surface and groundwater at its edges, i.e. in the areas of supply or drainage of groundwater. The forecast time changes shall then depend upon the character of the peripheral impacts, thus they shall be different in the case of the natural changes in hydrological conditions and different in the case of artificial structural interventions into contemporary hydrological conditions. In particular, the morphological changes in the river bed, contents of suspended sediments in the watercourse and natural colmatage of the watercourse belong amongst the natural changes in the hydrological conditions of the territories affecting the groundwater regime (Velísková, 2010; Gomboš, 2008). All the technical structural measures amending the conditions of supply and drainage 
of groundwater belong amongst the interventions into the waterworks conditions of the territories affecting the groundwater regime (Šoltész \& Baroková, 2004). In many cases, it is necessary to know not only the final condition achieved by the groundwater level after the implementation of any technical measure, but also the time after what the final condition is reached, or the time procedure of settlement of the new groundwater level status. That means, in general, the task regarding the long-term prognosis in the changes in the groundwater regime must be compiled as the task of unsteady flow of groundwater, where the reached final steady condition is the extreme case (Duba, 1964).

\section{The protective measures on the Danube River}

The designed waterworks complex consists of Gabčíkovo waterworks and Nagymaros waterworks which are, in terms of hydraulic, navigation, and energy distribution, a single operating system. The multipurpose hydroelectric project was built together with Hungary, according to an interstate Treaty signed in 1977. The waterworks complex on the Danube was designed to have an additional level at Nagymaros, consisting of a reservoir $95 \mathrm{~km}$ long and the Nagymaros power plant. This level was to be located between the Hungarian towns of Nagymaros and Visegrad and its purpose was to use the gradient of the reservoir for production of electricity and to allow ships to pass. When the Gabčíkovo Project was 90\% completed, Hungary stopped fulfilling its treaty obligations in 1989 and tried to end the Treaty in 1992 (www.gabcikovo.gov.sk).

In 1992, the Slovak party put into operation the Gabčíkovo waterworks using an alternative solution on the territory of the Slovak Republic (so called "C" variant) and it wholly completed the works on the object "Protective measures of the Nagymaros waterworks storage reservoir". The necessity of the construction of the object was implied by the reason of the prevention of an unfavourable impact of the dammed level of the Danube River by the Nagymaros step on the territory of the Slovak Republic. This was the reinforcement of the Danube River dam on the territory of the Slovak Republic, the Váh river dam, the Hron river dam and the Ipel' river dam. The backwater of the Danube River would prevent the gravitation outflow if the internal waters into the Danube River. The erected underground walls in the protective dams prevent the gravitation outflow of internal waters from the territory of the Slovak Republic in the Komárno - the Ipel' river estuary section, even when there is no backwater in the Danube River. For that reason the internal waters of the territory must be pumped into the Danube River through the erected pumping stations. The administrator of the river basis incurs increased costs related to the activity without their compensation. At the time of the decision of the Hungarian party on the termination of the works on the Nagymaros waterworks, the majority of the protective measures had already been implemented or in the uppermost stage of progress. Subsequently, their scope was minimised and they completed the objects related to

- the flood protection of the territory and

- the diversion of internal waters.

Protective measures against the level impoundment in the reservoir Nagymaros were built on the Slovak territory during the construction of Gabčíkovo waterworks. These consist of renovation of existing dams with newly built underground sealing walls, reinforcement of 
banks and building seepage canals. Protective measures include the construction of drainage channels and pumping stations and channels. Since the Hungarian side does not build up the lower reservoir, the operation will only be the Gabčíkovo waterworks and the protective measures established in the Slovak Republic that have been running for the maintenance of surface and ground water management at each water stage in the Danube River.

The Patince - Štúrovo section, RK 1751.8 to 1716.0

The construction of the underground walls in the Kravany nad Dunajom section RK 1746.6 to 1722.5 and in the Štúrovo section RK 1722.5 - 1716.0 took place in 03/1985 - 06/1996. There are two so called "windows" omitted in the non-permeable underground wall. The entire construction was carried out before 11/2002 (the data provided by Vodohospodárska výstavba š.p. Bratislava).

\section{Modelling and numerical simulation of groundwater flow in the Čenkov reparian alluvial aquifer}

\subsection{The long-term minimal anthropogenic disruption in natural conditions in of the study area}

The solution of groundwater flow features assessments, which are due to later anthropogenic investigations into the area are ranked as almost natural, are going out from the evaluation of former groundwater regimes based on observations in the nature, knowledge of geological structure of the area and hydrogeologic conditions, which is serving as a base to the water-level regime assessment and the subsequent assessment of the main groundwater flow directions.

The aim of the task to be solved is to create a numerical model for a steady groundwater flow in the reparian alluvial aquifer of the Čenkov plain, and its calibration, verification and obtaining of results by a simulation that is at groundwater level, using filtration velocity vectors, groundwater paths by particle tracking and the water budget. One assumption is that long-term minimal anthropogenics disrupted the natural conditions of the study area. As the date of the simulation was chosen on the day of 29 September 1954, because of the steady state of water flow through the study area, and also of the Danube low stage and because of existence of solving similar task by other methods in the past (Duba, 1964) and thereby available data needed for modelling and simulation.

\subsubsection{Description of study area}

The Čenkov plain is situated in the eastern part of the Danubian lowland, west apart from Šturovo town. It is the fluvial plain of the Danube, which borders in the south on a 23 kilometre long river section between RK 1722 and 1745 and in the north in an arc stretching across the terrace platform, where on its boundary lies the Moča village, the Búč village, the Júrsky Chlm village, the Mužla village and the Obid village. The fluvial plain is from $2.5 \mathrm{~km}$ up to $6 \mathrm{~km}$ wide and has an overall area of $66 \mathrm{~km}^{2}$. Its surface is flat. The heights of the terrain vary from 106 up to $108 \mathrm{~m}$ a.s.l. The lowest-situated section under the terrace is on height level $105 \mathrm{~m}$ a.s.l. and the highest situated section in the Čenkov wood is on the middle of the area $108-110 \mathrm{~m}$ a.s.l. (Fig. 1 and 2). 


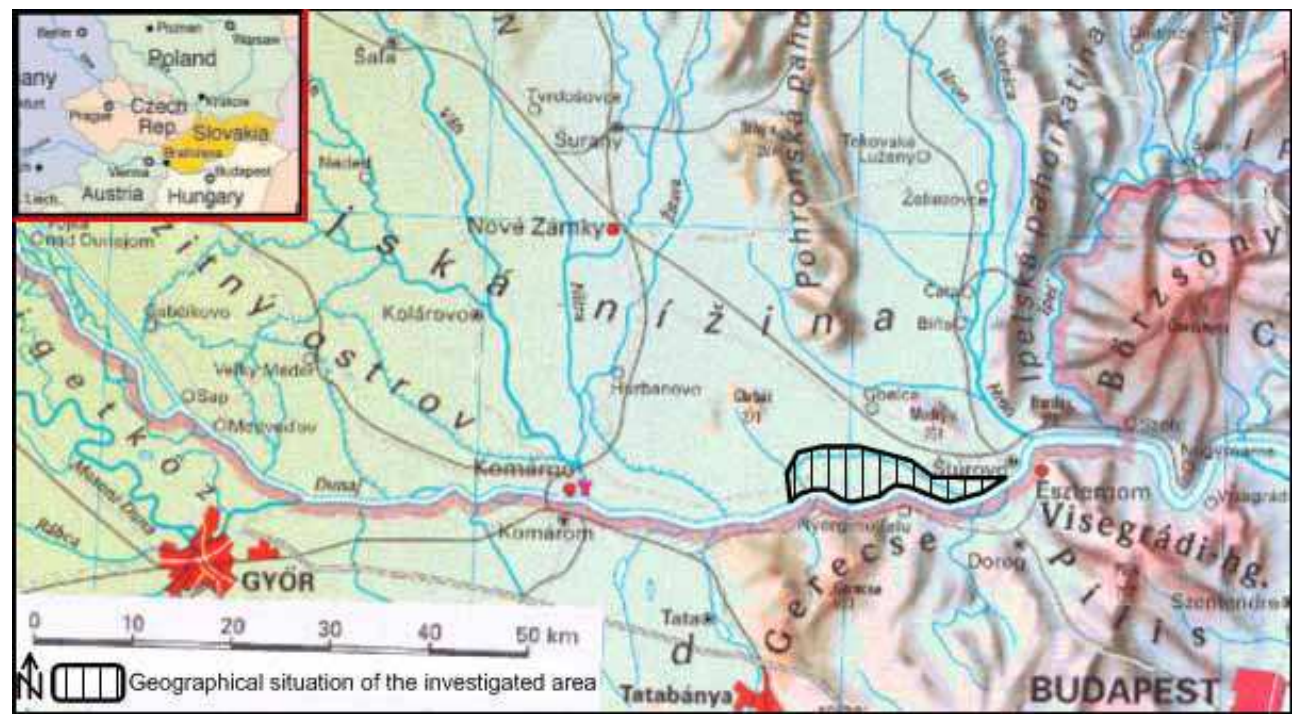

Fig. 1. Geographical situation of the Čenkov plain

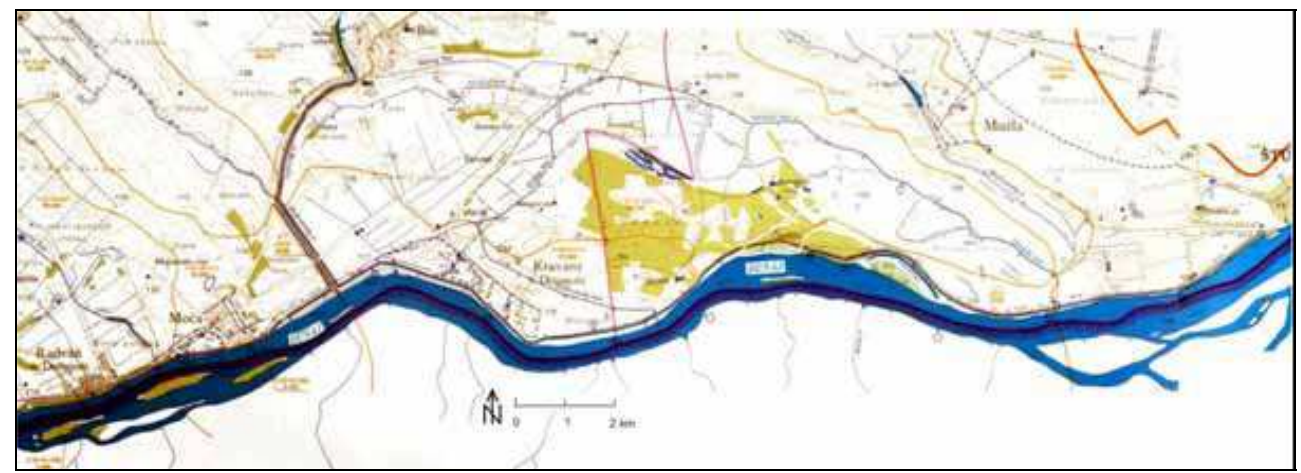

Fig. 2. Water management map of the Čenkov plain

\subsubsection{Evaluation of natural conditions}

\subsubsection{Climate}

From a climatic point of view the study area belongs to a warm locality in the scope of the south-eastern part of the Danubian lowland, where it has a warm and dry climatic zone with a mild winter. First, the temperature characteristics and yearly air temperature average shows that the south of Slovakia is the warmest locality of the republic. The average $10.4{ }^{\circ} \mathrm{C}$ at Štúrovo is convincing. Uniformity of moisture conditions is clear already from the yearly relative air moisture average, which varies from $74-81 \%$ and is the lowest in the bottom most parts of the Danubian lowland (Štúrovo $74 \%$, Komárno $75 \%$ ). In the territory of the West-Slovakia district, which is the most productive agricultural locality, the precipitation has significant importance. The centre of this locality is the Danubian lowland, which is 
indeed the warmest but also has the driest locality. In a series of long-term observations, the lowest annual precipitation totals vary in terms of $300-400 \mathrm{~mm}$ and minimum monthly precipitation totals in particular months do not even reach (except for July) $5 \mathrm{~mm}$ precipitation, whereupon significant dry periods are more often in summer half-year than in winter half-year. The lowest July precipitation totals do not drop under $10 \mathrm{~mm}$. On the other hand wet (precipitation) periods are lasting here mostly from 18 to 20 days, and their appearance is relatively more rare than the appearance of dry periods and it occurs mostly in spring and autumn periods. The highest annual precipitation totals could reach $900 \mathrm{~mm}$, even in singular cases up to $1000 \mathrm{~mm}$ of precipitation.

\subsubsection{Hydrogeology and geology}

The Danube fluvial plain at observed river sections is built by sediment deposits of the Danube River, where their thickness varies irregularly between $5-12 \mathrm{~m}$ and the most frequent thicknesses are between $6-9 \mathrm{~m}$. Gravel and sand dominate soil layers, which are in the highest part covered by alluvial loams. Gravel-sand fillings of the Danube fluvial plain's bed in this section belong to Würm, and the cover of sandy loam is Holocene.

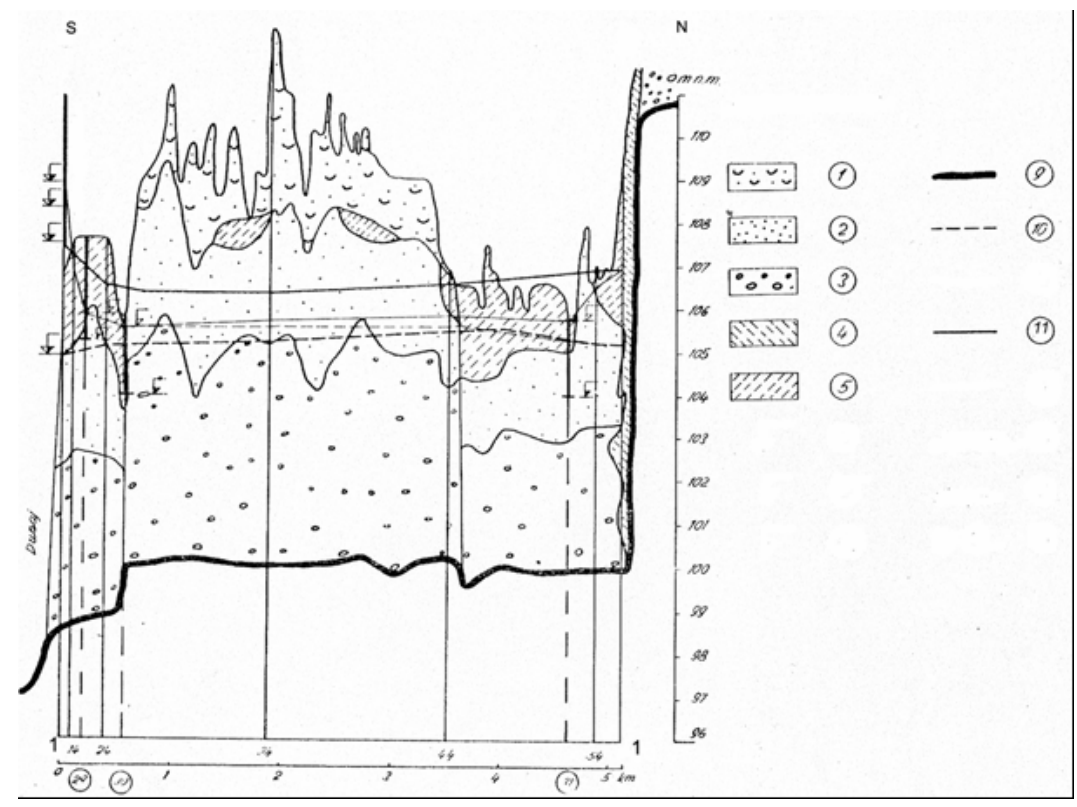

Fig. 3. Hydrogeological profile 1-1 (400x exceeded). Comments: 1-young Pleistocene blown sands, 2-medium to smooth sands, 3-sandy gravel to rough sands with gravel, 4-downhill loamy sediments along upper terrace step, 5-dusty to loamy sands, eventually dusty - sandy loams, 9- marking of the tertiary base surface, 10-groundwater level on 29 Sept.1954, 11-the highest groundwater level in years 1954 - 1956 (Duba, 1964)

It is possible to observe their partial subtilization in longitudinal profiles of gravel sand alluvia (Fig. 3 and 4) in the Danube direction, although the appearance of heavier gravel layers is possible in the whole profile. The left edge of the Danube's fluvial plain is lined by 
a markedly terraced step with relative height approximately $15 \mathrm{~m}$ and base $3 \mathrm{~m}$ above the Danube water level. Absolute height of the base is around $110 \mathrm{~m}$ a.s.l. it is slowly descending from the Chotin village to the Štúrovo town. Hydrogeological conditions of the terrace were proofed only by a few boreholes, after which hydraulic conductivity of gravel varies from $6.6 \mathrm{E}-05 \mathrm{~m} . \mathrm{s}^{-1}$ (the Chotín village) up to $2.0 \mathrm{E}-03 \mathrm{~m} \cdot \mathrm{s}^{-1}$ (the Štúrovo town - the Nana village). Groundwater recharge happens entirely from precipitation in locations where permeable blown sands or loamy sands and sandy loams are located in hanger. Groundwater from the terrace is drained on its edge to the lower step, partly on contact as it comes up to the surface and it is taken away by the drainage channels. The ground-water level in the alluvia is mainly influenced by the surface stream of the Danube River and then on other side by water seeping down from an adjacent terrace and through precipitation. The ground-water flow direction according to bilateral relation of the Danube water level and ground-water level was either to the aquifer or to the Danube.

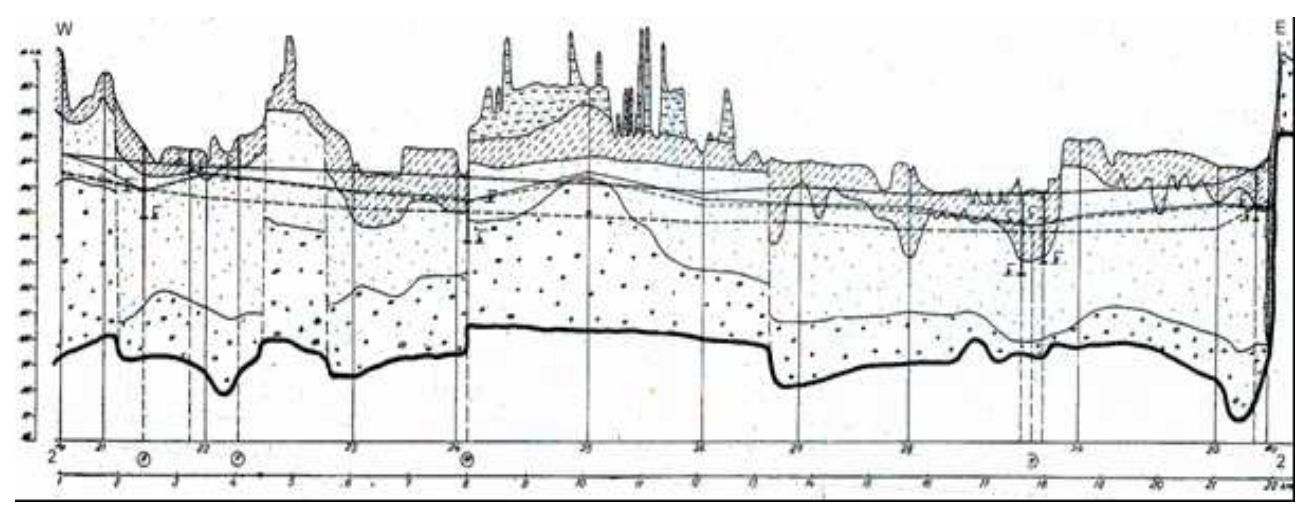

Fig. 4. Hydrogeological profile along the Danube bank (400x exceeded), (Duba, 1964)

\subsubsection{Hydrology}

Through the hydrological characteristics of the study area and the description of surface flows in an objective time it is necessary to concentrate on the Danube River, which has here first- rated importance. Slovak Danube river reach belongs to the upper part of middle part of the river. Danube is keeping its alpine character in Slovak reach, in its upper part it has considerable slope around $0.4 \%_{0}$, it is flowing in its own alluvia and it is creating multiple systems of river arms. Water stages are first of all dependent on the water supply from the Alps. Maximum water stage reaches the Danube in June at the time of alpine snow and glacier melting. From June it comes to permanent decrease and minimum water stages are reached in December and January. The Danube water stage on 29 September 1954 in RK 1742.9 (Radvaň nad Dunajom) was $105.20 \mathrm{~m}$ a.s.l. Other surface flows in study area are rather small and short and their discharges are low. The maximum occurs in spring months, and in summer their discharge is considerably decreased. Such streams are Modrianský potok (creek) (from Vel'ká Dolina), its left-hand side tributary Vojnický potok (creek), and Mužliansky potok (creek). Main channels: the Obidský, the Búčský, the Kraviansky and the Krížny channel belong to the system, as well as the large amount of side drainage channels without any name. 


\section{Methods and material}

\subsection{Modelling}

\subsubsection{Mathematical model of groundwater flow}

Three-dimensional groundwater flow of constant density through porous earth material may be described by a partial differential equation (McDonald, M.G. \& Harbaugh A.W., 1988):

$$
\frac{\partial}{\partial x}\left(K_{x x} \frac{\partial h}{\partial x}\right)+\frac{\partial}{\partial y}\left(K_{y y} \frac{\partial h}{\partial y}\right)+\frac{\partial}{\partial z}\left(K_{z z} \frac{\partial h}{\partial z}\right)-W=S_{s} \frac{\partial h}{\partial t}
$$

Where

$x, y, \mathrm{z}$ are Cartesian coordinates in the direction of main axis of hydraulic conductivity $K_{x x}$, $K_{y y}, K_{z z}, K_{x x}, K_{y y}, K_{z z}$ are the values of hydraulic conductivity in the direction of the axis of Cartesian coordinates $x, y, z$, which are assumed that they are parallel with major axis of hydraulic conductivity [L T-1], $h$ piezometric pressure head [L], $W$ volumetric flux per unit volume, which represents sources and (or) sinks of water [T-1], $S_{s}$ specific storage of the porous material [L-1], and $t$ time [T]. In general, $S_{s}, K_{x x}, K_{y y}$, and $K_{z z}$ may be the functions of space $\left(S_{s}=S_{s}(x, y, z)\right.$ a $K_{x x}=K_{x x}(x, y, z)$, etc. and $h$ and $W$ could be the functions of space and time $(h=h(x, y, z, t), W=W(x, y, z, t))$ which means that equation (1) describes groundwater flow for unsteady conditions in a heterogeneous and anisotropic medium, provided that the principal axes of hydraulic conductivity are aligned with the coordinate directions. Equation (1), together with the specification of flow and (or) head conditions on aquifer boundaries and specification of initial head conditions, creates a mathematical model of groundwater flow. A solution of equation (1), in an analytical sense, is an algebraic formula which indicates $h(x, y, z, t)$, so that when the derivatives of $h$, with respect to space and time are substituted into equation (1), the equation and its initial and boundary conditions are satisfied. Besides these very simple systems, it is possible to reach an analytical solution of equation (1) only rarely, so therefore it is necessary to use numerical methods for solution. One of the methods is the finite difference method, where the continuous system of equations (1) is substituted by the finite set of discrete points in the space and time, and the partial derivatives are substituted by terms calculated from the differences in head values at these points. Such an approach leads to the system of linear algebraic differential equations. Values of head in specific points in time are obtained by their solutions. These values represent approximation of the time-variable distribution of piezometric head, which could have been obtained by analytical solution of equation (1).

\subsubsection{Three-dimensional modular model of groundwater flow" MODFLOW"}

The finite difference model originally published by McDonald \& Harbaugh (1988), in the form of later modifications and addendums, and its modular computer program was utilized by the solution of the mentioned task. The modular structure consists of the "main program" and a series of independent subroutines called "modules". The explanation of physical and mathematical concepts, on which the model is based, and an explanation on how the modules are implemented into the structure of computer program, is listed in detail in the mentioned work. Ground-water flow in hydrogeological ground-water body is 
simulated by the use of a finite difference block-central method. The solution of systems of simultaneous linear equations is possible to obtain by various methods.

\subsubsection{Conceptual groundwater modelling}

\subsubsection{Definition of model's boundaries}

Northern to western boundaries of the modelled area are chosen regarding to the demarcation of hydrogeological groundwater body of the Čenkov plain from the northern side by the higher old-Würm terrace step. The Danube River creates the southern to eastern border (Fig. 2).

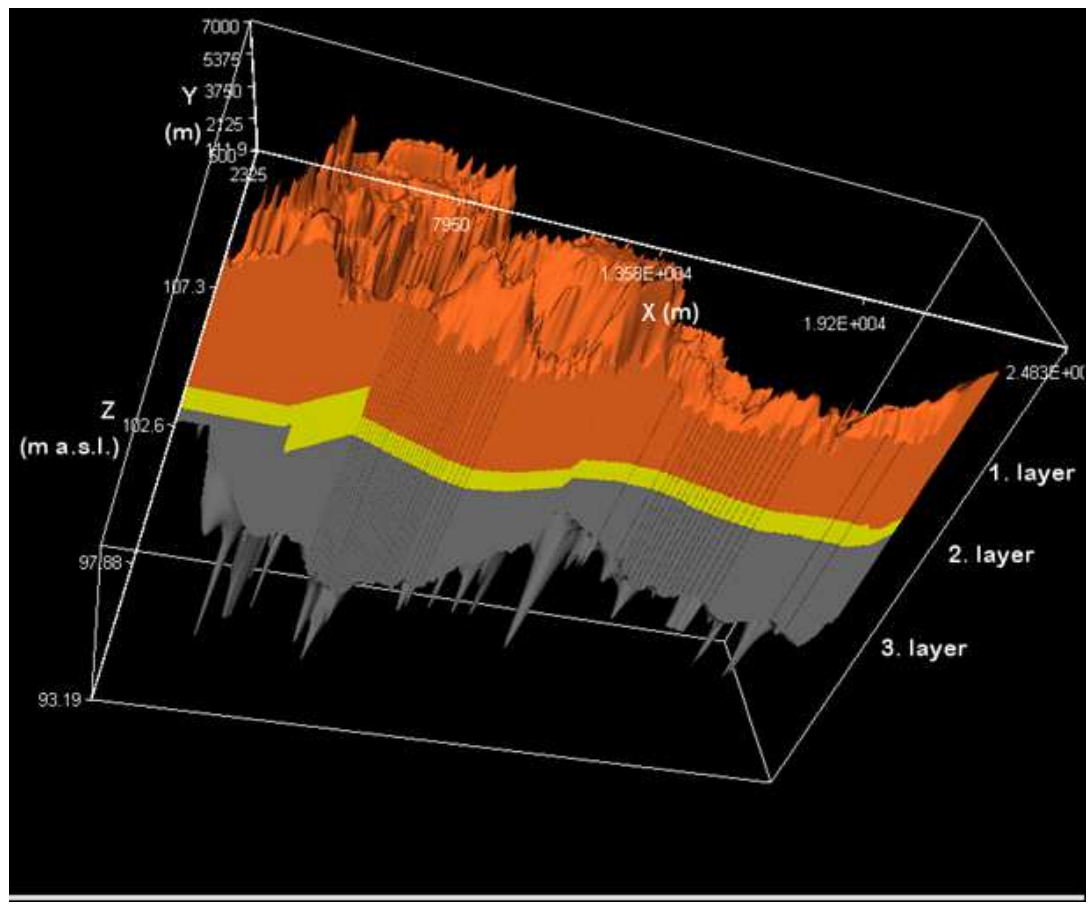

Fig. 5. The aquifer of the Čenkov plain

\subsubsection{Transformation of the hydrogeological system - vertical schematization}

The topography of the surface terrain was processed into digital format from maps with the scale of 1: 10 000. For purposes of modelling, the above described hydrogeological system was transformed into a three-layers system, which consists of an upper covering soil layer (1 $1^{\text {st }}$ layer $)$, of a medium to soft sand layer (2nd layer) and of a sandy gravel to rough sands with a gravel layer (3rd layer) (Fig. 5). These type of layers were selected for modelling as follows: $1^{\text {st }}$ layer: unconfined, $2^{\text {nd }}$ layer: confined/unconfined (transmissivity = const.), $3^{\text {rd }}$ layer: confined/unconfined (transmissivity $=$ const.). Thicknesses of particular layers were defined from geological and hydrogeological data from the survey. The surface of the tertiary base is considered impermeable. 


\subsubsection{Discretization in the space and time}

Hydrogeological systems are divided into a mesh of blocks called cells, the locations of which are described in terms of rows, columns, and layers. Footprint dimensions are picked so that the whole area of the Čenkov plain is covered with a smooth overlay. Dimensions of cells are: $\Delta x=\Delta y=50 \mathrm{~m}$. Geometry of the model is: $22.5 \mathrm{~km} \times 6.5 \mathrm{~km},(130$ rows and 450 columns); 3 layers. Grid orientation was picked in the direction of the general groundwater flow and coordinate axis $x, y, z$ are approximately parallel to the main hydraulic conductivity axis. Groundwater flow has always had a certain measure of unsteady flow. This results from natural conditions of recharge and drainage of groundwater. However, if the recharge and drainage groundwater conditions are changing in the time slightly, the flow is quasi-steady and practically represents certain boundary status. From the modelling target point of view a steady status of groundwater flow was considered to the date 29 September 1954.

\subsubsection{Filtration parameters of the aquifer}

Following filtration parameters were necessary for the modelling of this case: horizontal hydraulic conductivity, transmissivity, vertical hydraulic conductivity, effective porosity and coefficient of vertical leakage. Horizontal hydraulic conductivity of the groundwater body was obtained from the results of the hydropedological and hydrogeological survey in the study area. Data from pumping tests in probes and boreholes were globally processed by the means of interpolation method of kriging. Values vary from $7.48 \mathrm{E}-07 \mathrm{~m} \mathrm{~s}^{-1}$ to $3.99 \mathrm{E}-03 \mathrm{~m}$ $\mathrm{s}^{-1}$. Transmissivity of the layers was calculated as a multiple of horizontal hydraulic conductivity and thickness of the layer. Vertical hydraulic conductivity: by the modelling applications the usual ratio of the horizontal to vertical hydraulic conductivity is from 1 to 10 (Anderson \& Woessner, 1992). For the first and second layer ratio 1.0 was selected in compliance with results of the field research and for the third layer the ratio 2.0. Effective porosity is the feature of an aquifer to receive and to send out fluid in order to build hydrostatic pressure in the layer and through to the groundwater level. Quantitatively it is expressed by the coefficient of flexible storage and coefficient of free water level storage. The value of the coefficient of the free water level storage depends on hydraulic conductivity and also on grain size distribution of sediments and varies around 0.05 up to 0.15 for loamy sands, 0.15 for soft granulated to dusty sands, 0.19 for soft granulated sands, 0.22 for medium granulated sands and 0.24 for rough granulated sands, gravels etc. Estimated values of flexible storage for unit volume of the groundwater body are stated in the work of Mucha \& Šestakov (1987). Vertical leakage is required in the case of multiple layers groundwater body and represents the resistance to the water leakage at adjacent layers.

\subsubsection{Calibration and verification of the model}

Calibration is a process, when the initial input model parameters are adjusted until output (dependent) model parameters at most approach the values measured in the terrain. Calibration of the model is an inverse-model process, i.e. the problem of parameter estimation is an inverse problem. Calibration of the model or the inverse model process could be performed either repetitively, either on a manual basis by way of trial and error, or by using a special computer program. The calibration was executed by the means of the special computer program PEST with manual tuning of some zones. Calibration results for 
the status up to date 29 September 1954 are shown in Fig. 6. The difference between measured groundwater stages in probes from the Hydrometeorological Institute's observing network have calculated groundwater stages have a maximum value of $0.17 \mathrm{~m}$ and the regression coefficient has a value near to one, which refers to high correspondence of calculated results with measured results. The calibrated model of steady groundwater flow was verified at the low water stage in the Danube up to date 7 Aug. 2002 and at high water stage in the Danube up to date 7 May 2000. For both cases a very good accordance of measured and calculated groundwater levels was reached.

\section{Comparison of Calculated and Observed Heads}

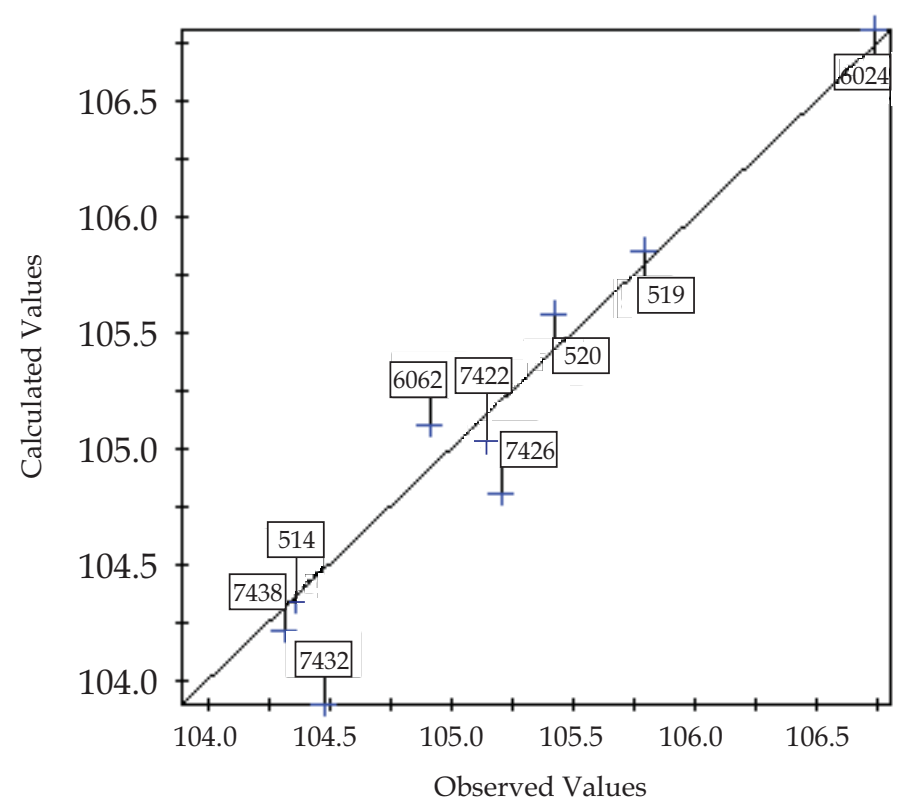

Fig. 6. Plot of calculated versus observed heads

\subsubsection{Simulated steady head distribution and flow lines}

Data about groundwater fluctuation has shown that the basic factors which are influencing groundwater level changes are atmospheric precipitation, bank filtration from the Danube river and underground inflow from the upper terrace direction north-west and on the northern edge of the area, then evapotranspiration, and underground outflow to the Danube (draining effect of the Danube) and outflow through the drainage canals.

On Fig. 7 we can see that the drainage effect of the Danube is from RK 1745 to RK 1733 and from RK 1727 to RK 1722, and this presents altogether $17 \mathrm{~km}$ of bank filtration drainage systems in the river. Bank filtration recharge is from RK 1733 to RK 1727 and that is $6 \mathrm{~km}$ bank length of the Danube. The line of direct drainage influence of the Danube goes from the Moča village along the edge of the terrace step to the Búč village, where it turns to the south approximately to the Mária farmstead whence it continues in a southern-easterly 
Change of Groundwater Flow Characteristics After Construction of the

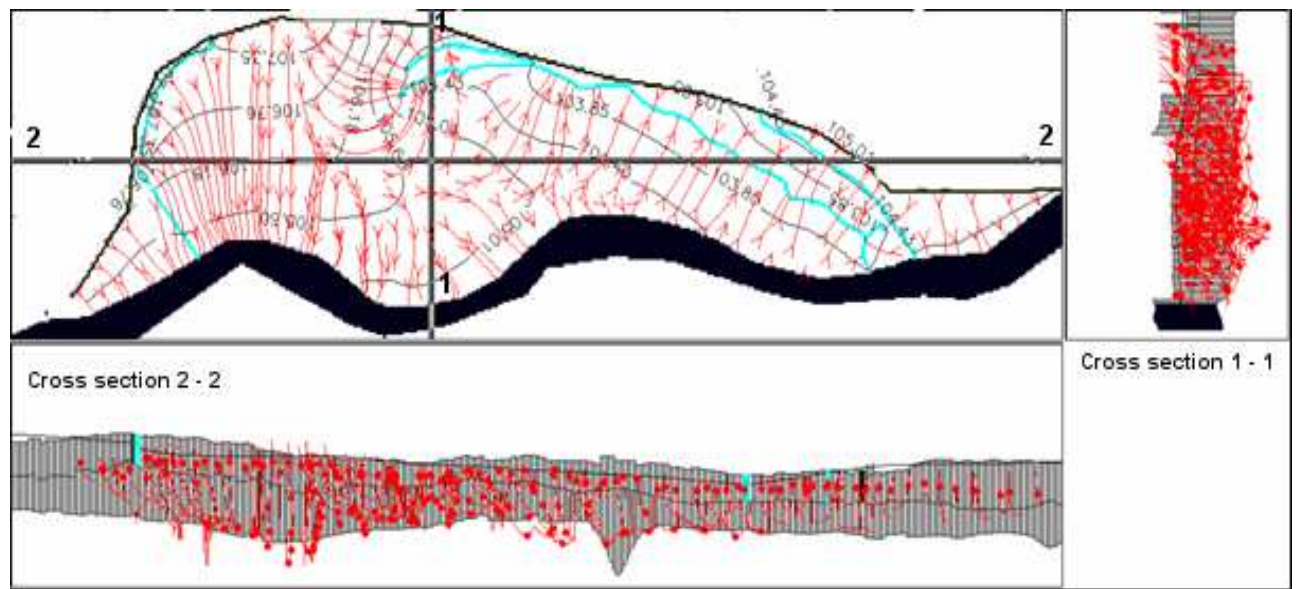

Fig. 7. Simulated steady head distribution and flowlines in the second model layer

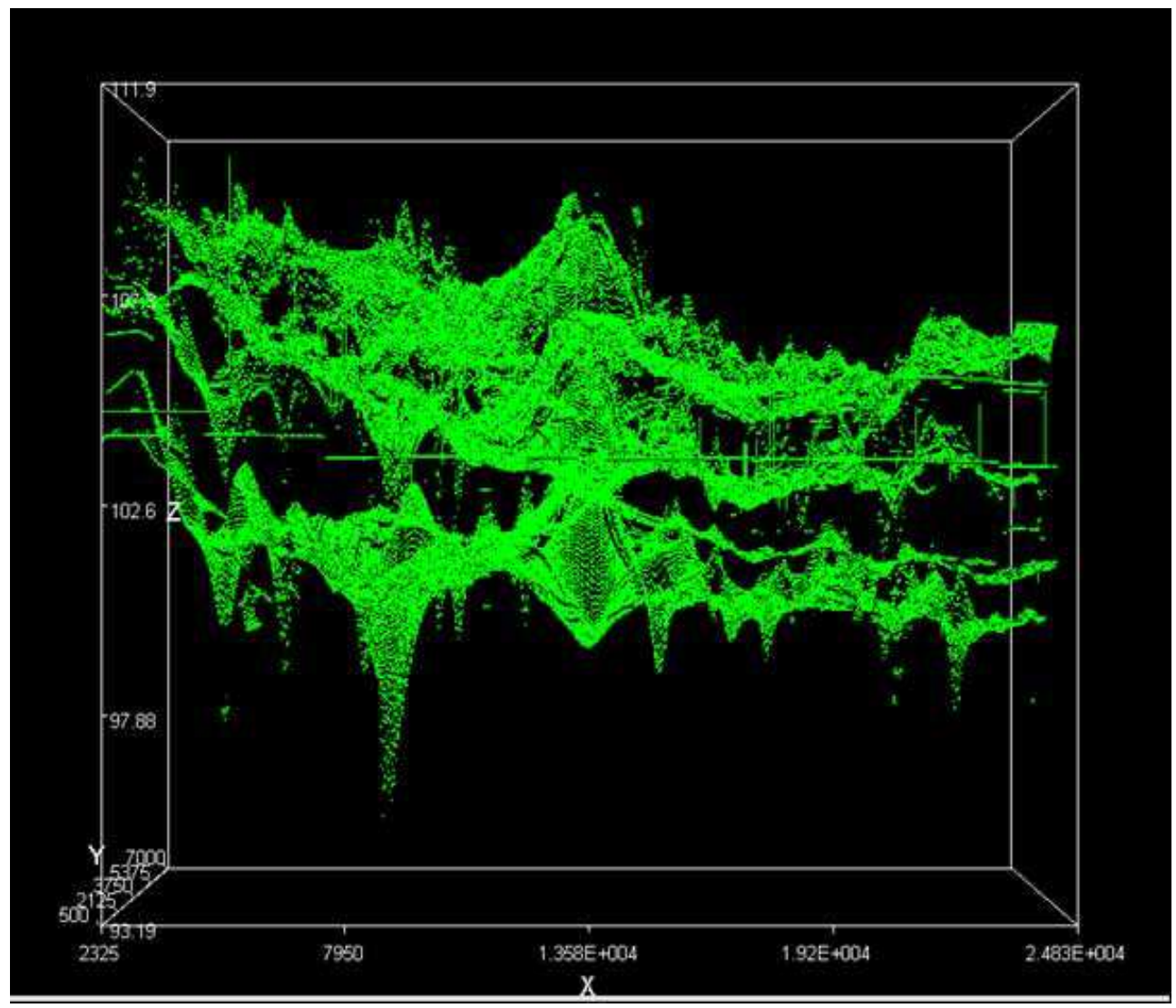

Fig. 8. 3-D visualization of filtration velocity vectors - view from south 
direction to the river in the Čenkov locality. The second drainage area is bounded from the south from the Obid canal river mouth to the Danube up to the Štúrovo town and from the north by the "Pod kopanicami" drainage canal. The feeding effect of the river is decreased by the drainage of lower parts of the Mužliansky creek and the Obid canal. The remaining part of the study area is drained by the local system (the Obid, Krížny and Búčsky canal). On Fig. 8 there is a 3D visualization of the whole groundwater body, with velocity vectors in the second layer of the groundwater body where there are the highest filtration velocities along the Obid canal and Mužliansky creek and at their river mouths, and also along the bank of the Danube (drainage) around RK 1742. Similarly in the third layer, there are the highest filtration velocities along open streams and along the Danube bank from RK 1744 to RK 1742 and around RK 1729. The range of filtration velocity values in the whole groundwater body varies from $1 \mathrm{E}-10 \mathrm{~m} \cdot \mathrm{s}^{-1}$ to $1.19 \mathrm{E}-03 \mathrm{~m} \cdot \mathrm{s}^{-1}$. Particle tracking is used for the tracing of the groundwater flow directions, which means creating flow lines by carrying out the tracing of infinitely small imaginary elements movement situated in the flow field. In the reach from the Moča village to the Čenkov settlement groundwater flow into the Danube except the northern part in which groundwater flows to the drainage canals. From the Obid canal mouth to the Danube River (RK 1727) up to the Štúrovo town groundwater flow direction is again into the Danube. The volume water budget for the whole model at the end of the simulation is calculated in order to control the results. It indicates acceptation of the numerical solution. Continuity has to be preserved also for the total model inflow and outflow or sub region of the layer. The difference in the water budget of the study area is $0.01 \%$ the difference should be in ideal case smaller than $0.1 \%$, what is fulfilled. In general an error up to $1 \%$ is accepted (Konikow \& Bredehoeft, 1978).

\section{The hydrological classification of groundwater regimes}

The basic regime specificities of the fluctuation of groundwater level in the alluvial plains and terraces of rivers in dependence upon the fluctuation of the level in a watercourse may be observed only if the natural conditions create the possibility of the hydrodynamic continuity between the level in the surface watercourse and groundwater. If such a relation is possible, then three zones may be earmarked according to the regime symptoms of the groundwater level fluctuation on the riverine territory:

- In the first zone, that is called the narrower riverine zone, every fluctuation of the level of the surface watercourse corresponds with the fluctuation of the groundwater level, of course with the higher distance from the watercourse characterized by the increase in the phase shift and reduction of amplitude. In a certain distance from the watercourse, due to the increased resistance of the porous environment (it is proportional to the length) lower fluctuations in the watercourse level stop influencing the fluctuation of the groundwater level and the next zone is entered.

- In second zone, called wider riverine zone, only greater fluctuations of the watercourse level or the water conditions with longer duration affect the fluctuation of the groundwater level. Its external demarcation (in the direction from the river to the outskirts of the territory) is considered to be the join of the points in which the horizontal straight line plotted at the height of the maximal river level crosses the highest underground level in the riverine valley cross-sections. The river level may not directly influence the groundwater level behind this line via bank filtration. 
- In third zone, called the external riverine zone, the groundwater level is always higher than the watercourse level. Despite that it is considered to be the riverine zone, since the gradual direct increase in the groundwater level in narrower and wider riverine zone increases the base for the groundwater drainage of the external riverine zone, in which their level may raise as a consequence of the fact the underground inflow has more difficult outflow conditions and vice versa. Then also the territory is indirectly affected by the outflow river regime - its level fluctuation.

It is clear the boundary between narrower and wider riverine zone, similarly as between wider and external riverine zone is conventional to the certain degree. It must be understood to the intent that its determination pursuant to the stated principles is based upon a certain length of observation time, during which all somehow extreme situations need not to occur. The most distant demarcation of the external riverine zone shall be the edge of the terraced step of the bottom land or other its demarcation at the contact with other hydrogeological units.

If the natural conditions are anthropogenically influenced and create a limited possibility of a hydrodynamic link between the level of the surface stream and groundwater, as it is in the case of the constructed underground non-permeable seating wall (the "NSW") between the Danube River and hydrogeological collector with omitted sections in the NSW, so called "windows", the demarcation of the boundaries between the zones is more difficult. The coefficients of determination for the individual boreholes are considered, while they are very important for the assessment of the degree of dependence between the level of the Danube River and the groundwater level. The boundary between narrower and wider riverine zone shall be determined using two-dimensional models of groundwater flow, displaying the isolines of piezometric groundwater heads and the vectors of filtration speed. The boundary is changed in dependence upon the level condition in the watercourse. The average width of narrower riverine zone of the Danube River at the left side of the lower Váh River in the proximity of an "window" is approximately $2500 \mathrm{~m}$ and it is approximately $2300 \mathrm{~m}$ on the Cenkov plain. Wider riverine zone is earmarked by the boundary of hydrogeological region Q 057 in both cases.

\section{Analyses and comparison of representative groundwater regime of the territory before, and after construction of protective measures}

The processing of the observed data and creation of numerical models enables the clarification of the laws of the groundwater regime, in particular to determine its fundamental characteristics, which are: the level heights and main directions of the groundwater flow, depth of the groundwater level under the terrain, the fluctuation of the underground level, the lines of development of changes of the groundwater level in time, volumetric budget and hydrogeological profiles.

The height of levels and main directions of groundwater flow shall be determined using the isolines of the piezometric heights of groundwater level (piezometric contours; for a free level ground water table contours) as the basic document. Firstly they are constructed for the characteristic conditions of the factors that may affect the groundwater regime, according to the knowledge of the hydrogeological and geomorphological conditions of the territory and the preliminary assessment of the observed data. They are the extreme cases of the occurrence of the meteorological factors, such as the periods after extraordinary heavy 
rainfall or after prolonged rain-free periods. In addition, they are construed also for the periods of the occurrence of the extreme and average conditions of the groundwater for the observation period. Such processing produces the basic data on the conditions of supply and drainage of the groundwater within the territory.

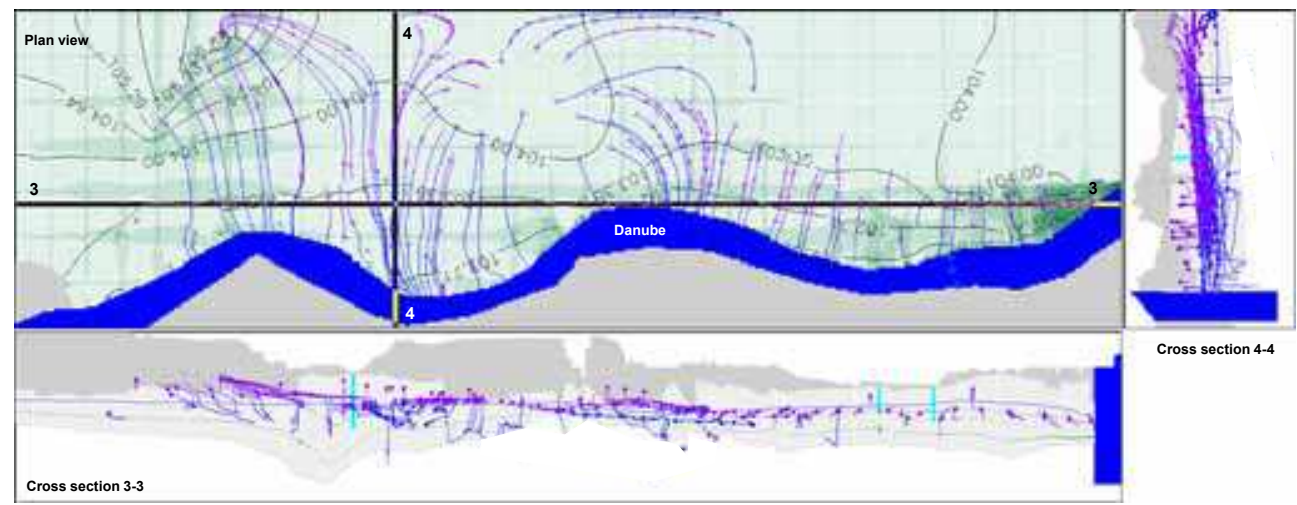

Fig. 9. Steady state head distribution (black lines, $m$ a.s.l. ), flowlines (blue lines in the third model layer, purple lines in the second model layer) and velocity vectors(green, $\mathrm{m} . \mathrm{s}^{-1}$ ) in the $3^{\text {rd }}$ model layer before the construction of protective measures - minimum water stage of the Danube

Contour levels: min. $101.42 \mathrm{~m}$ a.s.l., max. $104.43 \mathrm{~m}$ a.s.l. Flowlines: the direction of the flow of groundwater is from the aquifer to the Danube River lengthwise. Velocity vectors: maximal speeds of the groundwater flow are at the Vojnice brook beyond the effluent from the Búčsky pond in second model layer and somehow smaller speeds are in the Eastern part of the territory of interest at Štúrovo, at Čenkov and at the proximity of the Modranský brook in the third model layer. Maximum value of horizontal pore velocity is $5.11 \mathrm{E}-04 \mathrm{~m} . \mathrm{s}^{-1}$ and maximum vertical pore velocity is $3.89 \mathrm{E}-07 \mathrm{~m} \cdot \mathrm{s}^{-1}$ (Fig. 9).

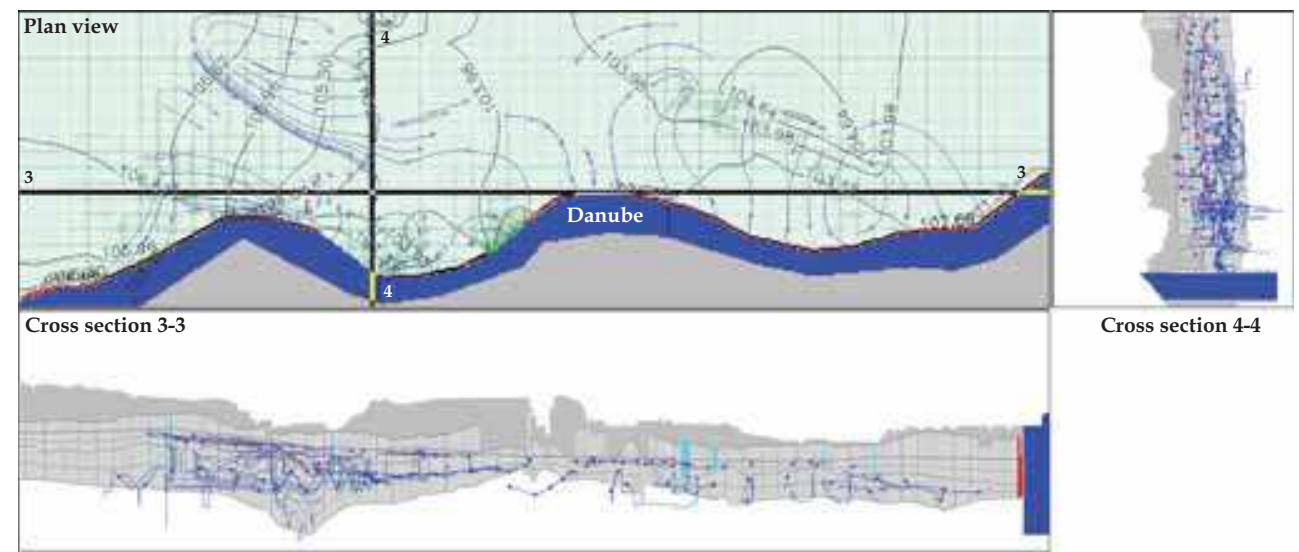

Fig. 10. Steady state head distribution, flowlines and velocity vectors in the $3^{\text {rd }}$ model layer after the construction of protective measures - minimum water stage of the Danube 
Contour levels: min. $101.34 \mathrm{~m}$ a.s.l., max. $107.94 \mathrm{~m}$ a.s.l. Flowlines: the groundwater flows from the aquifer from the Búčšsky pond to the Danube River via the "window" next to Kravany. Smaller amount of groundwater flows to the Danube River via the "Window" at Čenkov. Velocity vectors: the maximal speeds of the groundwater flow are in the Eastern zone of the water source of Kravany towards the wells. Maximum value of horizontal pore velocity is $1.23 \mathrm{E}-03 \mathrm{~m} \cdot \mathrm{s}^{-1}$ and maximum vertical pore velocity is $8 \mathrm{E}-08 \mathrm{~m} . \mathrm{s}^{-1}$ (Fig. 10).

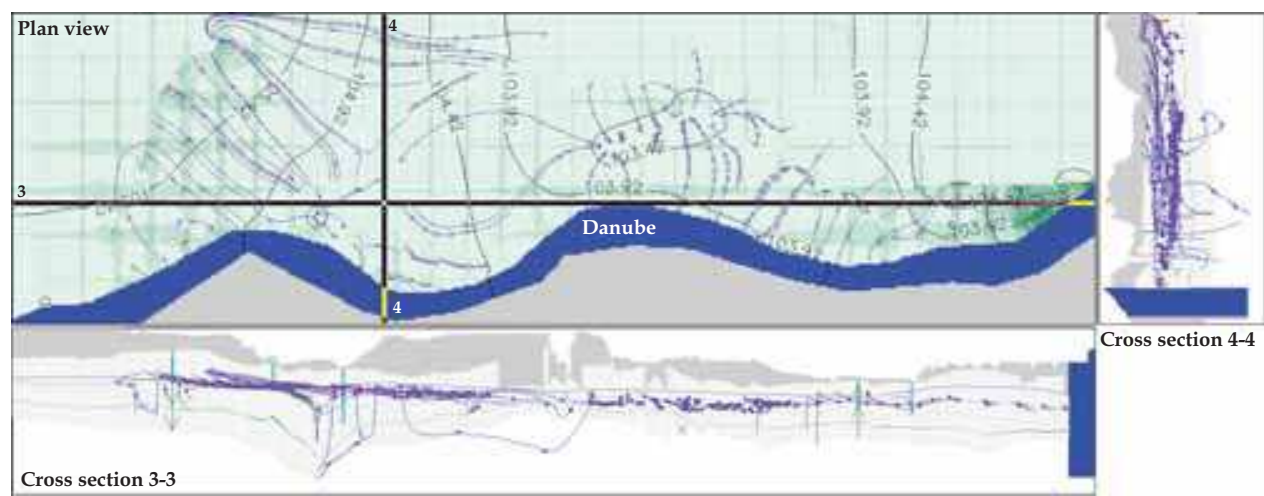

Fig. 11. Steady state head distribution, flowlines and velocity vectors in the $3^{\text {rd }}$ model layer before the construction of protective measures - average water stage of the Danube

Contour levels: min. $103.32 \mathrm{~m}$ a.s.l., max. $107.91 \mathrm{~m}$ a.s.l. Flowlines: the Western half of the territory of interest is drained by the Danube River. The water source of Kravany drains the circular zone up to the Kravany channel. The aquifer is supplied from the settlement of Čenkov up to the pumping station Obid by the Danube River. The interior is drained by and water is conducted away by the drainage channels, in particular the Obid and Mužla ones. Velocity vectors: the maximal speeds of flow are around the water source of Kravany in second model layer and somehow lower ones are in the Eastern part of the territory of interest in the section of Obid - Štúrovo in third model layer. Maximum value of horizontal pore velocity is $4.32 \mathrm{E}-04 \mathrm{~m} . \mathrm{s}^{-1}$ and maximum vertical pore velocity is $4.21 \mathrm{E}-09 \mathrm{~m} . \mathrm{s}^{-1}$ (Fig. 11).

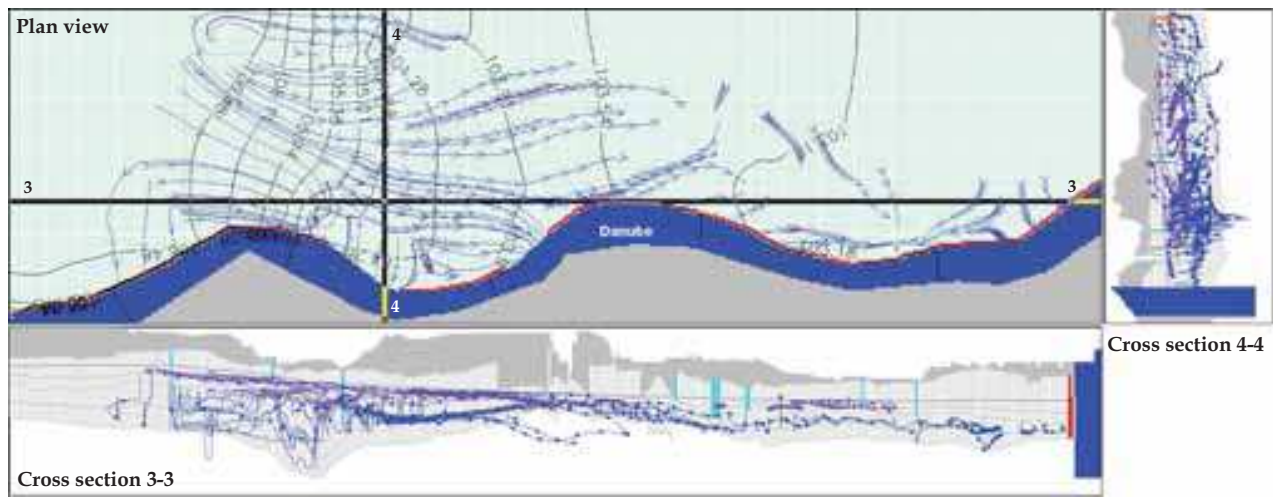

Fig. 12. Steady state head distribution, flowlines and velocity vectors in the $3^{\text {rd }}$ model layer after the construction of protective measures - average water stage of the Danube 
Contour levels: min. $102.79 \mathrm{~m}$ a.s.l., max. $107.95 \mathrm{~m}$ a.s.l. Flowlines: the aquifer drains the Danube River via the window at Kravany approximately from the territory of the intravillain of the village of Kravany. The aquifer drains significantly more via second window at Čenkov, where it takes out the groundwater from the water reservoir at the village Búc. The interior is drained by and water is conducted away by the system of drainage channels, in particular the Obid channel. Velocity vectors: the highest speeds of flow re in second model layer around the water source of Kravany. Maximum value of horizontal pore velocity is $1.13 \mathrm{E}-03 \mathrm{~m} . \mathrm{s}^{-1}$ and maximum vertical pore velocity is $1.06 \mathrm{E}-07$ m.s $\mathrm{s}^{-1}$ (Fig. 12).

Contour levels: min. 104.00 m a.s.l., max. 109.53 m a.s.l. Flowlines: the Danube River fills the aquifer lengthwise. The groundwater is drained in the interior by and conducted away by the system of drainage channels. Velocity vectors: the maximal speeds of flow are between the Kravany channel and the Danube River in second model layer. Maximum value of horizontal pore velocity is $9.42 \mathrm{E}-03 \mathrm{~m} \cdot \mathrm{s}^{-1}$ and maximum vertical pore velocity is $5.82 \mathrm{E}-07$ m.s $\mathrm{s}^{-1}$ (Fig. 13).

Contour levels: min. $102.50 \mathrm{~m}$ a.s.l., max. $109.53 \mathrm{~m}$ a.s.l. Flowlines: The Danube River supplies the entire aquifer via both windows. The groundwater is drained in the interior by and conducted towards the pumping stations by all drainage channels. Velocity vectors: the maximal speeds of flow are in the area between the Kravany channel and the Danube River in second model layer. The highest speeds of flow of the groundwater in third model layer are in the intravillain of the village of Kravany and at Čenkovo. Maximum value of horizontal pore velocity is $7.67 \mathrm{E}-04 \mathrm{~m}^{-1} \mathrm{~s}^{-1}$ and maximum vertical pore velocity is $6.70 \mathrm{E}-08$ m.s $\mathrm{s}^{-1}$ (Fig. 14).

Depth of the groundwater level under the terrain is conditioned by its height and morphology of the area. The significance of the processing of depth at analogous water stages as the isolines of piezometric heights lies in the fact they enable to assess the possibility of supply of groundwater from rainfall or their drainage by evapotranspiration in dependence upon the

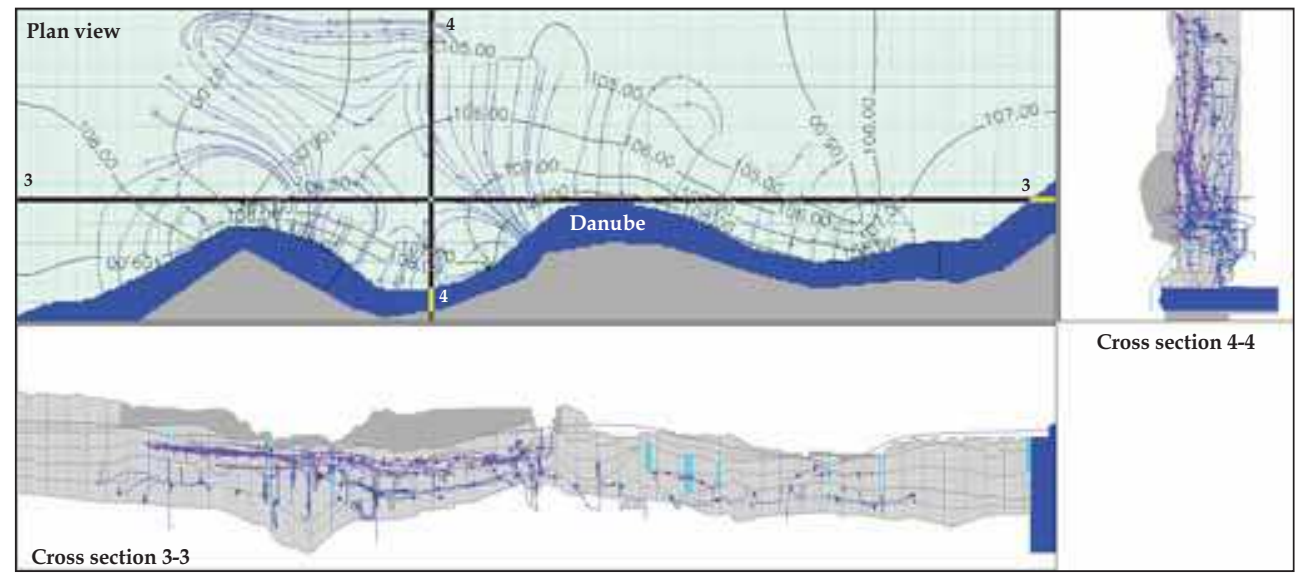

Fig. 13. Steady state head distribution, flowlines and velocity vectors in the $3^{\text {rd }}$ model layer before the construction of protective measures - maximum water stage of the Danube 
composition of the surface deposits. When comparing the depths with the thickness of layer of the surface deposits, in the case of their little permeability they enable to assess the groundwater flow regime, thus to earmark the areas or periods with the occurrence of tense or free level of groundwater.

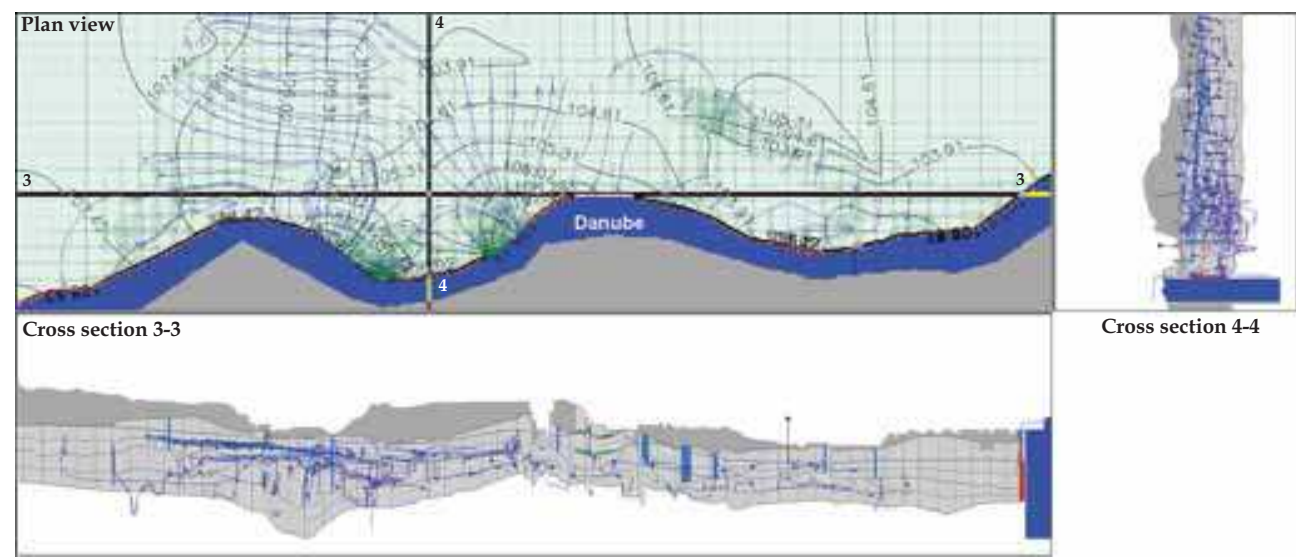

Fig. 14. Steady state head distribution, flowlines and velocity vectors in the $3^{\text {rd }}$ model layer after the construction of protective measures - maximum water stage of the Danube

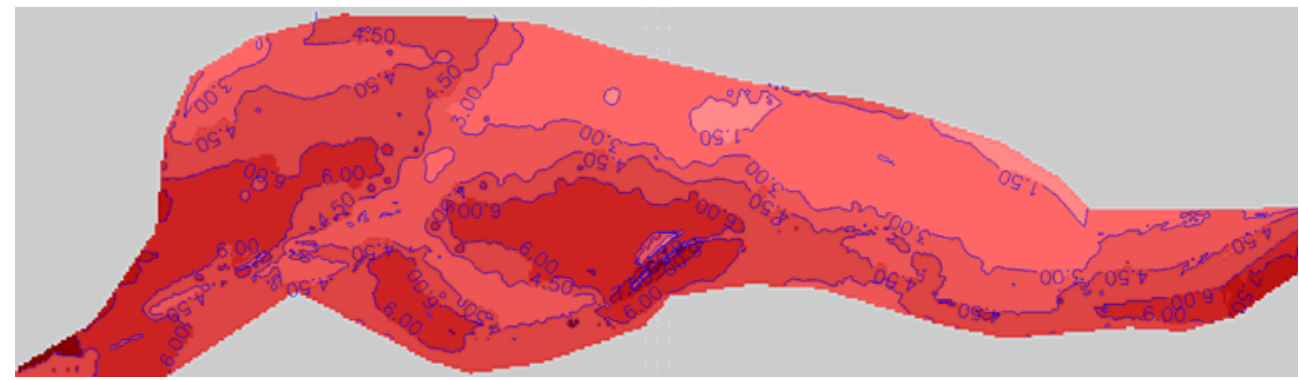

Fig. 15. Depth of groundwater level below the ground surface at minimum water stage of the Danube before the construction of protective measures (m)

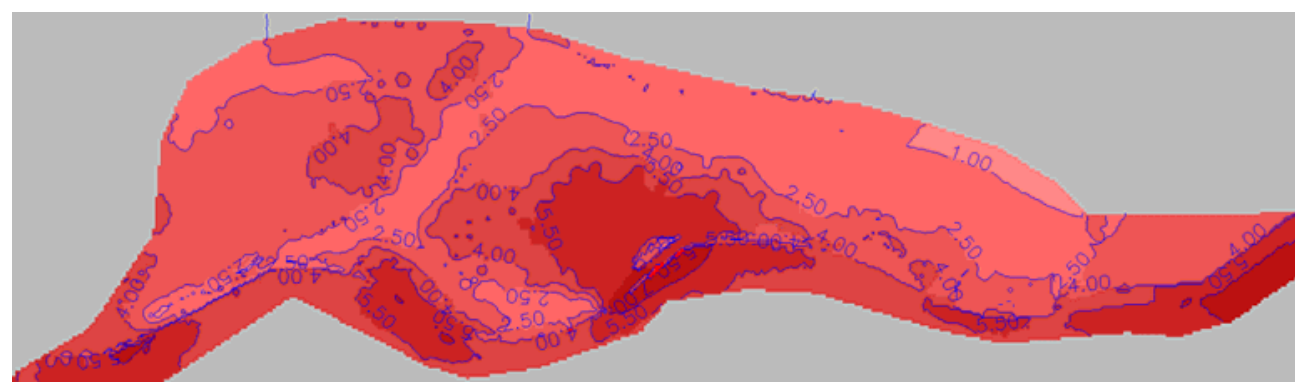

Fig. 16. Depth of groundwater level below the ground surface at minimum water stage of the Danube after the construction of protective measures (m) 
The maximal groundwater level depth is up to $8.5 \mathrm{~m}$ under the terrain surface and it occurs at the Western border of the territory of interest between the village of Moča and the Modriansky brook. The minimal depth is $2.00 \mathrm{~m}$ and it is located at the drainage channels, in particular the Obid, the Krížny and Mužliansky brooks (Fig. 15).

The maximal groundwater level depth is up to $8.0 \mathrm{~m}$ under the terrain surface and it occurs in the route of the window in the underground non-permeable wall at Čenkov. The minimal depth is $0.00 \mathrm{~m}$ and it is located at the boundary of the territory to the East of the village of Mužla (Fig. 16).

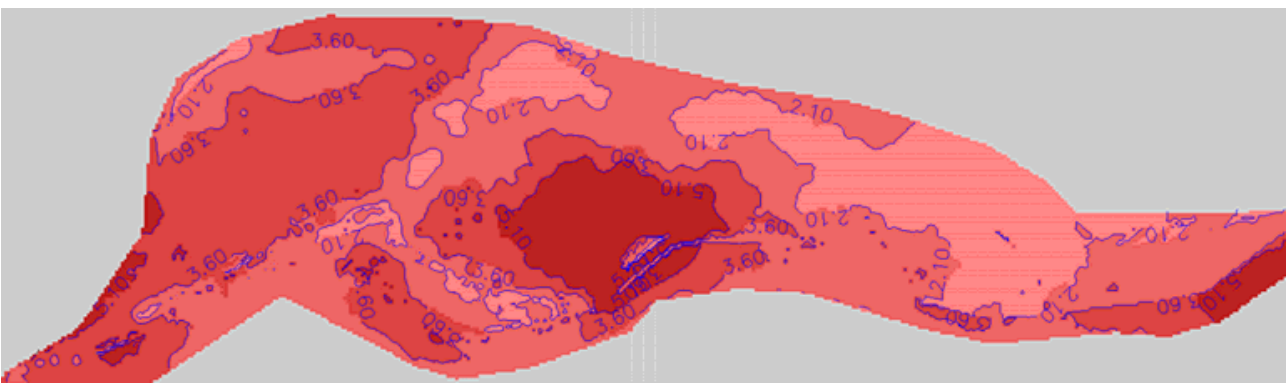

Fig. 17. Depth of groundwater level below the ground surface at average water stage of the Danube before the construction of protective measures (m)

The maximal groundwater level depth is up to $6.30 \mathrm{~m}$ under the terrain surface and it occurs in the Southern part of the Čenkov forest. The minimal depth is $0.60 \mathrm{~m}$ and it is located to the South next to the intravillain of the village of Mužla (Fig. 17).

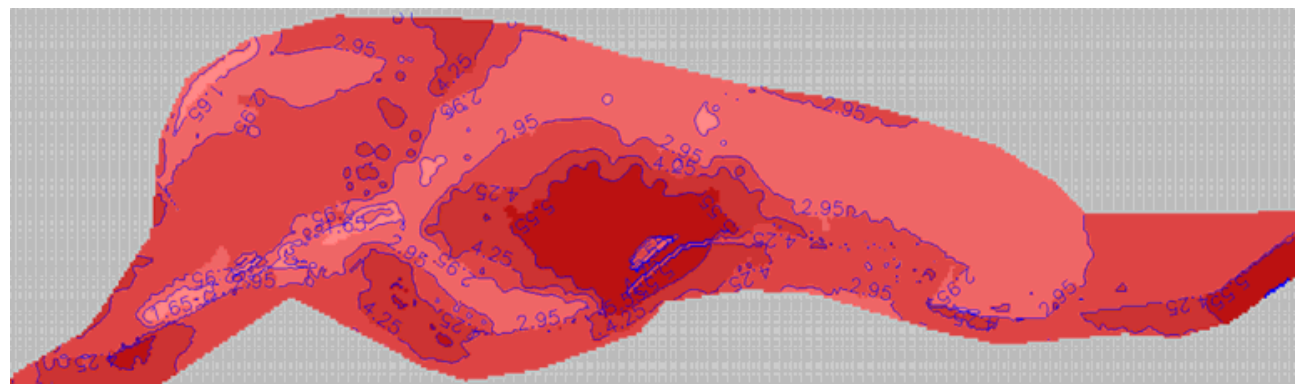

Fig. 18. Depth of groundwater level below the ground surface at average water stage of the Danube after the construction of protective measures $(\mathrm{m})$

The maximal groundwater level depth is up to $6.86 \mathrm{~m}$ under the terrain surface and it occurs in the Southern part of the Čenkov forest. The minimal depth is $0.34 \mathrm{~m}$ and it is located at the beginning of the Kravany channel (Fig. 18).

The maximal depth of the groundwater level is $4.37 \mathrm{~m}$ under the terrain surface and it occurs at the Western border of the territory of interest between the village of Moča and the Modriansky brook. The piezometric pressure head reaches the value of $3.29 \mathrm{~m}$ above the terrain surface in the proximity of the pumping station Obid (Fig. 19). 


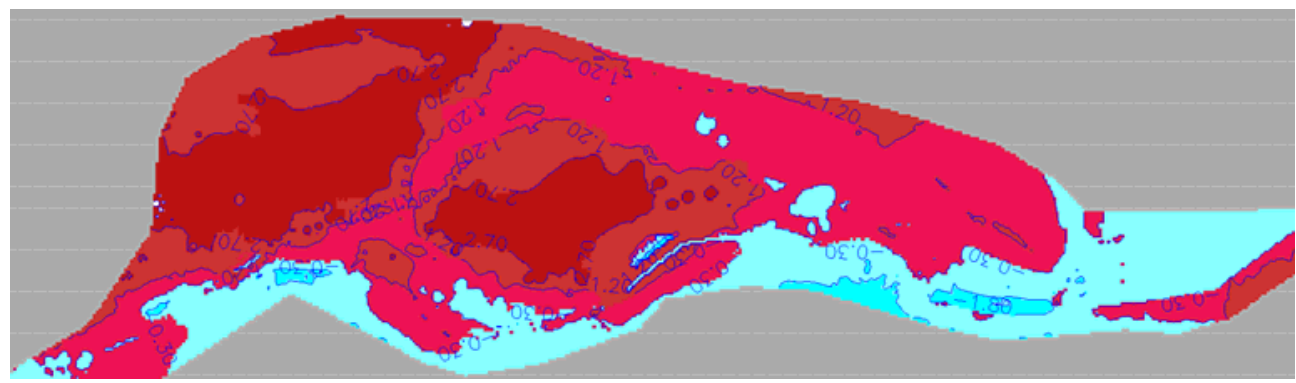

Fig. 19. Depth of groundwater level below the ground surface at maximum water stage of the Danube before the construction of protective measures $(\mathrm{m})$

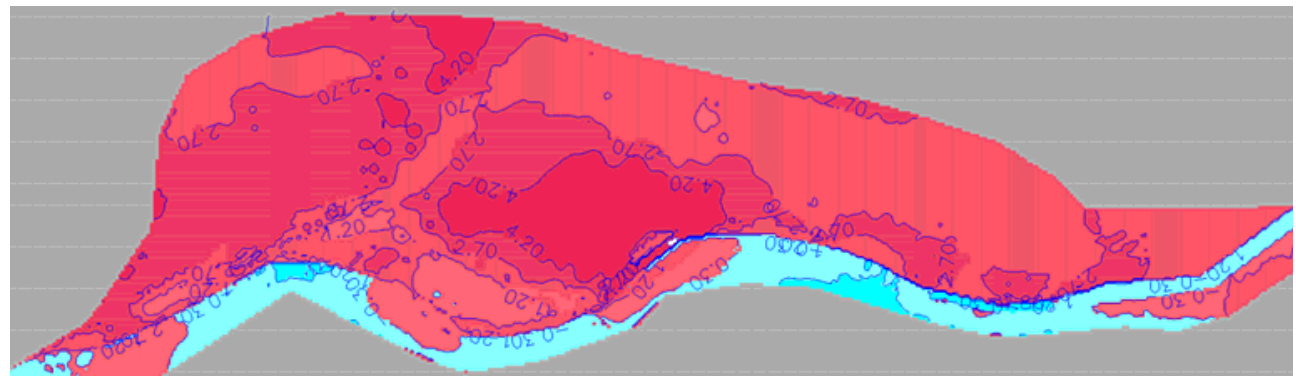

Fig. 20. Depth of groundwater level below the ground surface at maximum water stage of the Danube after the construction of protective measures $(\mathrm{m})$

The maximal groundwater level depth is up to $5.76 \mathrm{~m}$ under the terrain surface and it occurs in the Southern part of the Čenkov forest. The piezometric pressure head reaches the value up to $0.5 \mathrm{~m}$ above the terrain surface in the intravillain of the village of Kravany (Fig. 20).

Fluctuation of groundwater levels, plotted as the difference between the extreme heights or depths under the terrain for the observation period, determines the maximal amplitude of the fluctuation on the particular observation spot that may be depicted using the lines with the same fluctuation. From the isolines, it is then possible to determine, when comparing with the values of the fluctuation in the surface recipients and the values of rainfall, as well

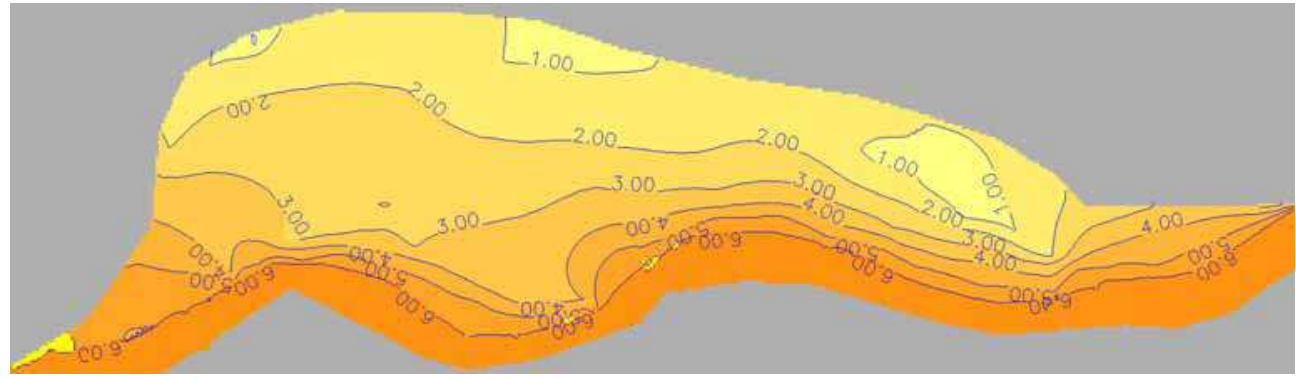

Fig. 21. The difference between the maximum and minimum groundwater level before the construction of protective measures (m) 
as the meteorological data characterizing the total evapotranspiration, also the regime specificities of the particular territorial units.

The difference between the maximum and minimum groundwater level before the construction of protective measures reaches the maximal values up to $6.48 \mathrm{~m}$ on the narrow strip alongside the entire non-permeable underground wall. To the North towards the interior, the differences are diminished and they reach the minimal values down to $0.00 \mathrm{~m}$ on the Northern border of the territory of the interest (Fig. 21).

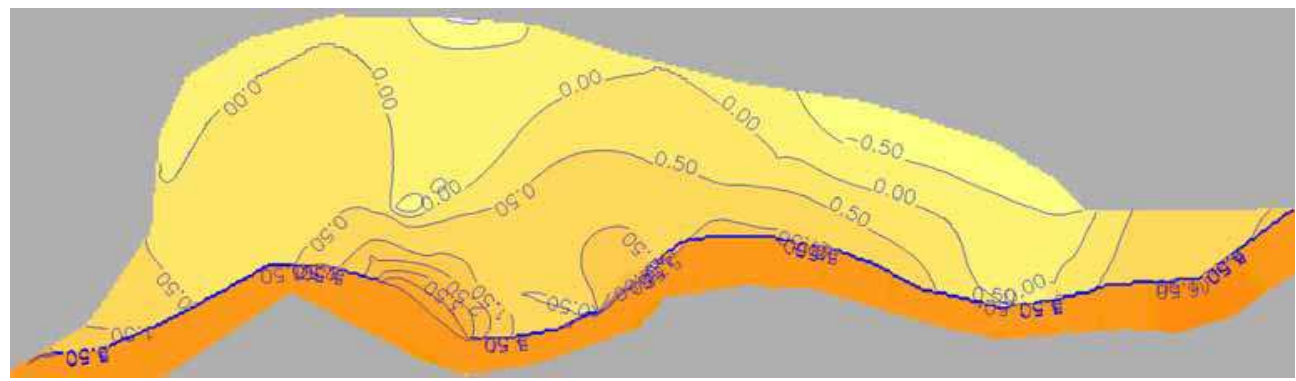

Fig. 22. The difference between the maximum and minimum groundwater level after the construction of protective measures (m)

The difference between the maximum and minimum groundwater level after the construction of protective measures reaches the maximal values up to $6.6 \mathrm{~m}$ in the window at Kravany and negative values down to $2.38 \mathrm{~m}$ on the Northern border of the territory (Fig. 22).

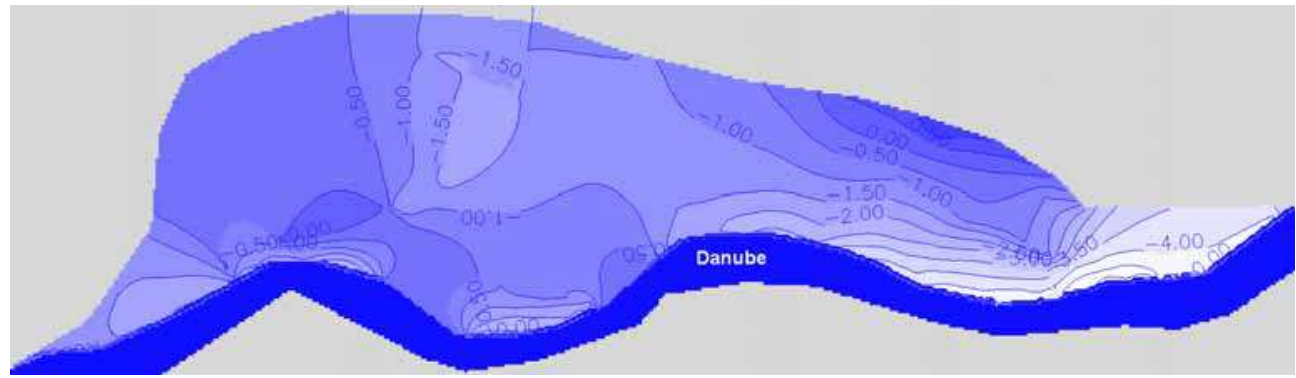

Fig. 23. The difference of groundwater level at the maximum water stage of the Danube (this means groundwater level after the construction of protective measures minus before the construction) (m)

Time slope lines of the changes of the groundwater levels, created for a prolonged observation period from the entire observation network (the SHMÚ, or other boreholes on purpose), together with the hydrogeological profiles form the fundamental preconditions for the demarcation of the territorial units and areas with the prevailing impact of the individual influences, inducing the supply or drainage of groundwater. These impacts are: underground inflow from the rivers or any other surface water recipients, underground inflow from the neighbouring hydrological or hydrogeological units, surface inflow and 
outflow, surface outflow to the rivers or reservoirs and other surface recipients, underground outflow into other catchment areas or hydrogeological units, rainfall infiltrating on the particular territory, the overall evapotranspiration reducing the stock of groundwater in the case of shallow saturated collectors.

Volumetric budget. A summary of all inflows and outflows to a region is generally called a water budget. In this case, the water budget is termed a volumetric budget because it deals with volumes of water and volumetric flow rates; thus strictly speaking it is not a mass balance. A water budget provides an indication of overall acceptability of the solution. The system of equations solved by the model actually consists of a flow continuity statement for each model cell. The water budget is calculated independently of the equation solution process, and in this sense may provide independent evidence of a valid solution (McDonald, M.G. \& Harbaugh A.W.,1988).

The displayed exponential dependence on Fig. 24 from the results of calculations of volume budget show that the approximate limit of the change in the groundwater outflow from the aquifers to the Danube River is an average water stage of the Danube of $104.5 \mathrm{~m}$ a.s.l. Water stages of the Danube River exceeding the limit cause low, approximately the same outflow of groundwater from the aquifers to the Danube River both before and after the construction of the protective measures. At water stages of the Danube River below the specified limit the differences in the outflow are increased and at the minimal water stage of the Danube River of $102.5 \mathrm{~m}$ a.s.l. the groundwater outflow $\left(\mathrm{m}^{3} . \mathrm{s}^{-1}\right)$ after the completion of the protective measures is approximately five times lower than it was before the completion of the protective measures.

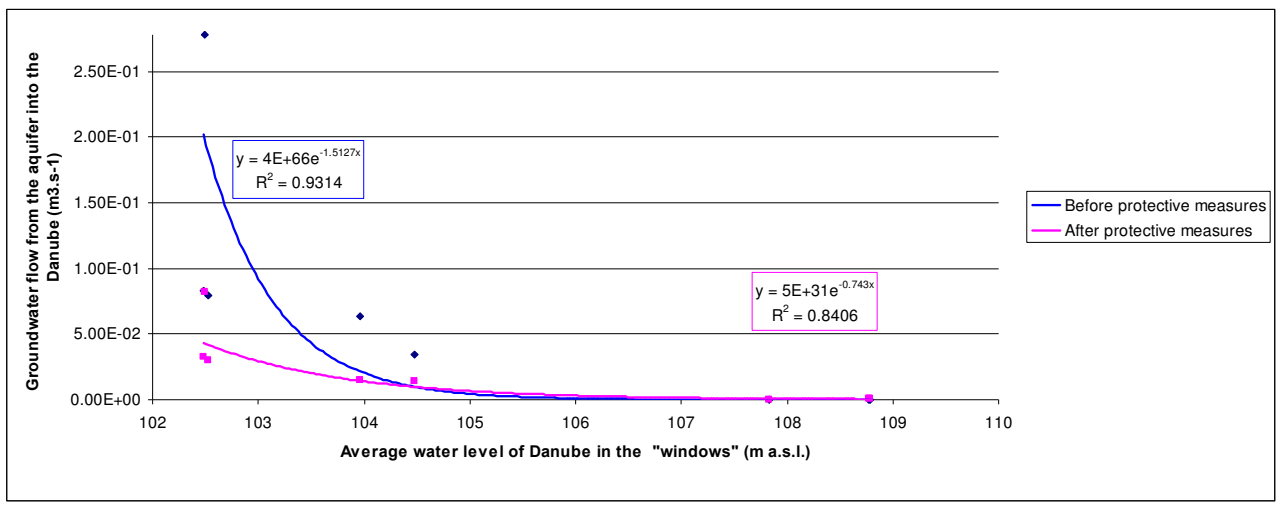

Fig. 24. Groundwater flow from the aquifer into the Danube River $\left(\mathrm{m}^{3} \cdot \mathrm{s}^{-1}\right)$

Similarly, for the flow of water from the Danube River to the aquifer the relation may be expressed using the exponential dependence (Fig. 25). At the minimal water stage of the Danube River the dependence is almost the same before and after the completion of the protective measures. The differences in the flows are exponentially increased between the average and maximal water stage of the Danube River and at the high water stage of the Danube River after the completion of the protective measures the flow of water from the Danube River to the aquifer is more than fivefold lower than it was before the completion of the protective measures. 


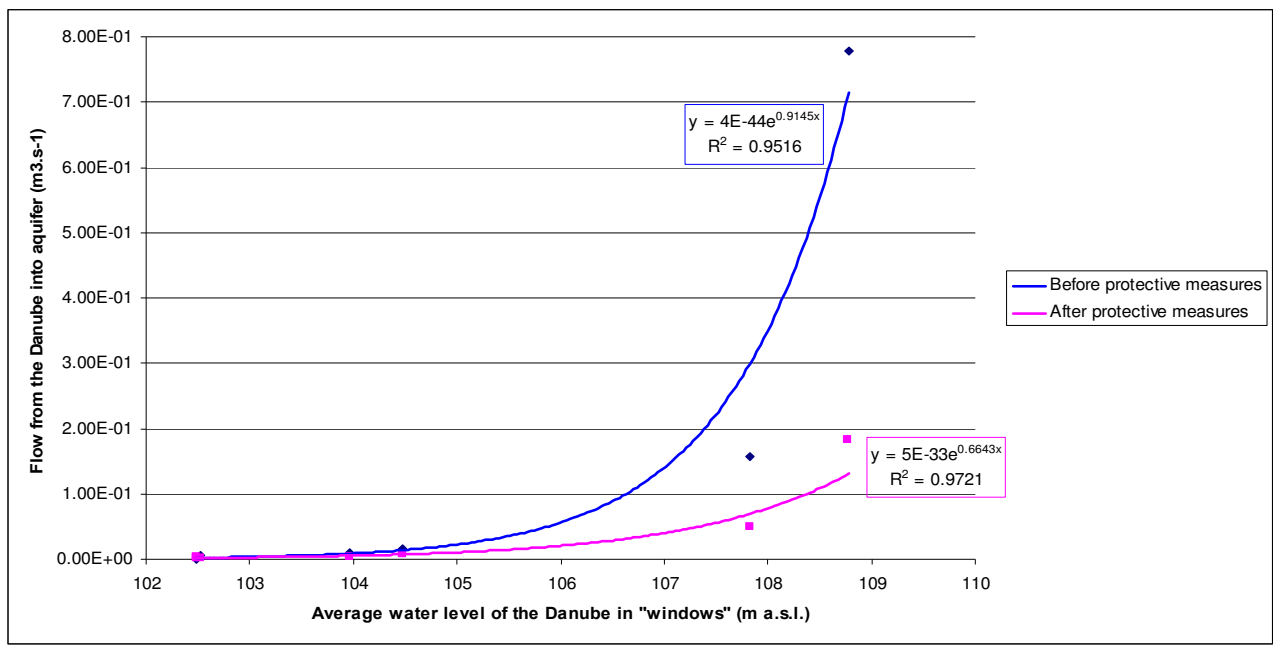

Fig. 25. Flow from the Danube River into the aquifer $\left(\mathrm{m}^{3} \cdot \mathrm{s}^{-1}\right)$

Hydrogeological profiles (Fig. 4 and 5) with displayed characteristic levels of groundwater, when they are plotted perpendicularly to the surface water recipients, allow to specify the assessment of the impact of the immediate influence of the fluctuation of their level onto the fluctuation of the groundwater level, they allow to determine the distance of the drainage effect of rivers, reservoirs, the inclination of the groundwater level and underground inflow to the observed territory or the underground outflow from it. The hydrogeological profiles alongside the rivers are important for the calculations of the overall bank filtration inflow and outflow. They allow to determine the flow regime, whether it is done with a free level or tense level. Finally, they are very graphic prove for the demarcation of the areas with the intensive inflow and outflow of groundwater, i.e. the areas of their accumulation, or drainage.

\section{Conclusions}

The processing of the observed data and creation of numerical models enables the clarification of the laws of the groundwater regime, in particular to determine its fundamental characteristics, which are: the level heights and main directions of the groundwater flow, depth of the groundwater level under the terrain surface, the amplitude of the underground level, the lines of development of changes of the groundwater level in time, volumetric budget and hydrogeological profiles. For the purpose of the assessment of the change of the characteristics of the groundwater flow after the construction of the protective measures of the Nagymaros waterworks the condition before the construction of the protective measures was analysed and compared with the condition after the construction of the protective measures (the PMs.) The results imply that:

1. The groundwater level is after the construction of the protective measures:

- at the minimal water stage of the Danube River higher than before the erection of the PMs on the prevailing portion of the territory of interest (max. by $3.45 \mathrm{~m}$ ), It is lower on the location of Búčšska lúka and Pod kopanicami (max. by $1.45 \mathrm{~m}$ ), 
- $\quad$ at the average water stage $\mathrm{f}$ the Danube River in the Western third of the territory (max. by $1.6 \mathrm{~m}$ ) and also on the location of Kendeleš (max. by $0.17 \mathrm{~m}$ ) higher than before the completion of the PMs. Lower (max. by $2.25 \mathrm{~m}$ ) on the remaining territory,

- at the maximal water stage of the Danube River on the Northern border at the village of Mužla (max. by $1.15 \mathrm{~m}$ ) and in the proximity of the Kravany channel (max. by $0.35 \mathrm{~m}$ ) higher than before the completion of the PMs.

2. The main directions of the flow after the completion of the protective measures:

- at the minimal water stage of the Danube, the change of the direction of the groundwater flow is significant in the Western half of the territory, from the Northern border of the territory to both "windows",

- at the average water stage of the Danube River, the groundwater from the area of Kravany flows to the Danube River via both "windows" and not to the location of Kendeleš,

- at the maximal water stage of the Danube, the aquifer is supplied from the Danube not alongside its bank length, but only via the "windows" in the underground wall.

3. The groundwater level depth under the terrain surface after the construction of the protective measures:

- at the minimal water stage of the Danube the maximal depth of groundwater level was reduced by $0.5 \mathrm{~m}$ and the minimal depth reached the level of the terrain surface,

- $\quad$ at the average water stage of the Danube the maximal depth of groundwater level was increased by $0.56 \mathrm{~m}$ and the minimal depth was reduced by $0.36 \mathrm{~m}$,

- at the maximal water stage of the Danube River the maximal depth of the groundwater level was increased by $1.39 \mathrm{~m}$. The piezometric pressure head above the terrain surface was reduced by $2.79 \mathrm{~m}$.

4. The fluctuation of the groundwater level after the construction of the protective measures:

- maximal value of the fluctuation was increased by $0.12 \mathrm{~m}$. The minimal value was increased by $2.38 \mathrm{~m}$.

5. Volumetric budget:

- At water stages of the Danube River below $104.5 \mathrm{~m}$ a.s.l. the differences in the outflow of groundwater from the aquifer to the Danube River are increased and at the minimal water stage of the Danube River of $102.5 \mathrm{~m}$ a.s.l. the groundwater outflow $\left(\mathrm{m}^{3} \mathrm{~s}^{-1}\right)$ after the completion of the protective measures is approximately five time lower than it was before the completion of the protective measures. Roughly exponential relation applies here.

- The differences in the flows are exponentially increased between the average and maximal water stage of the Danube River and at the high water stage of the Danube River after the completion of the protective measures the flow of water from the Danube River to the aquifer is more than fivefold lower than it was before the completion of the protective measures.

Future research should focus on numerical simulations of the underground dam function in the riparian alluvial aquifer. Underground dam belongs to the management types of artificial hydrogeological groundwater body feeding. It is built in shallow alluvial sediments in order to restrain the immediate underground outflow from the groundwater body. It 
consists of impermeable wall situated along surface flow, which is dropped to the neogene. Artificial groundwater body feeding, which results from integrated surface and groundwater utilization and long lasting sub-surface accumulation, is preferred where it is possible. Artificial feeding has important role by repeated water utilization, because it gives also quality advantages (water clarifying in soil and in groundwater bodies). In order to utilize the underground reservoir for the storage of significant water amount with the intention to utilize it in later period, it is necessary to discover potential accumulation capacity of the groundwater reservoir as well as its convenience for feeding from surface water and easy pumping in the case of necessity. Groundwater reservoir should show sufficient free space between surface terrain and groundwater level for the water storage and water reservation from feeding during the period when the water is not necessary.

\section{Acknowledgment}

Author would like to express thanks to the Grant Agency of Slovak Academy of Sciences VEGA for the financial support from projects No 2/0123/11 and No 2/0130/09.

\section{References}

Anderson, M.P. \& Woessner, W.W. (1992) Applied groundwater modelling. Academic press, Inc., California

Duba, D. (1964) Solution of changes in groundwater level caused by Nagymaros dam construction. Geologické práce, Zprávy 32, Bratislava, pp. 91-104 (In Slovak)

Gomboš, M. (2008). Water storage dependability in root zone of soil. Cereal Research Communications, Vol.36, No.1, pp. 1194-1194, ISSN 0133-3720

Chiang, W.H. \& Kinzelbach W. (2001) 3D-Groundwater Modelling with PMWIN. A Simulation System for Modelling Groundwater Flow and Pollution, Springer-Verlag Berlin Heidelberg, ISBN 3-540-67744-5

Konikow, L.F., \& Bredehoeft, J.D. (1978) Computer model of two-dimensional solute transport and dispersion in groundwater.U.S. Geological Survey Techniques of Water-Resources Investigations, Book 7, chap. C2, 90 p.

McDonald, M.G. \& Harbaugh A.W. (1988) A modular 3-D finite difference groundwater flow model. USGS, U.S. Geological Survey Open-File Report 83-875, Book 6

Mucha, I. \& Šestakov, V.M. (1987) Groundwater Hydraulics. ALFA-SNTL, Bratislava-Praha (In Slovak.)

Silva, W.P. \& Silva, C.M.D.P.S. (1999-2010) LAB Fit Curve Fitting Software (Nonlinear Regression and Treatment of Data Program) V 7.2.47 online, available from http:/www.labfit.net

Šoltész, A. \& Baroková, D. (2004) Analysis, prognosis and control of groundwater level regime based on means of numerical modelling. In: Global Warming and other Central European Issues in Environmental Protection: Pollution and Water Resources, Columbia University Press, Vol.XXXV, Columbia, pp.334-347, ISBN 80-89139-06-X

Velísková, Y. (2010) Changes of water resources and soils as components of agro-ecosystem in Slovakia. Növénytermelés, Vol. 59, suppl., pp. 203-206, ISSN 0546-8191

http://www.gabcikovo.gov.sk 


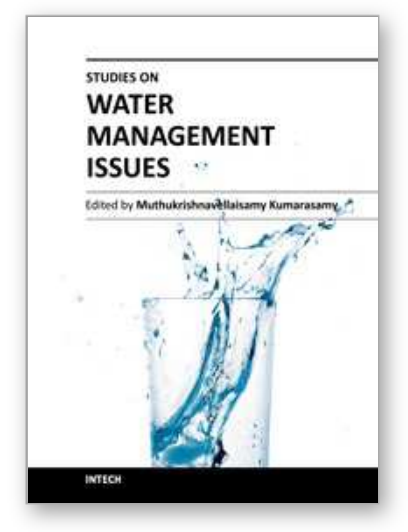

\author{
Studies on Water Management Issues \\ Edited by Dr. Muthukrishnavellaisamy Kumarasamy
}

ISBN 978-953-307-961-5

Hard cover, 274 pages

Publisher InTech

Published online 18, January, 2012

Published in print edition January, 2012

This book shares knowledge gained through water management related research. It describes a broad range of approaches and technologies, of which have been developed and used by researchers for managing water resource problems. This multidisciplinary book covers water management issues under surface water management, groundwater management, water quality management, and water resource planning management subtopics. The main objective of this book is to enable a better understanding of these perspectives relating to water management practices. This book is expected to be useful to researchers, policy-makers, and non-governmental organizations working on water related projects in countries worldwide.

\title{
How to reference
}

In order to correctly reference this scholarly work, feel free to copy and paste the following:

František Burger (2012). Change of Groundwater Flow Characteristics After Construction of the Waterworks System Protective Measures on the Danube River - A Case Study in Slovakia, Studies on Water Management Issues, Dr. Muthukrishnavellaisamy Kumarasamy (Ed.), ISBN: 978-953-307-961-5, InTech, Available from: http://www.intechopen.com/books/studies-on-water-management-issues/change-of-groundwater-flowcharacteristics-after-construction-of-the-waterworks-system-protective-me

\section{INTECH}

open science | open minds

\section{InTech Europe}

University Campus STeP Ri

Slavka Krautzeka 83/A

51000 Rijeka, Croatia

Phone: +385 (51) 770447

Fax: +385 (51) 686166

www.intechopen.com

\section{InTech China}

Unit 405, Office Block, Hotel Equatorial Shanghai

No.65, Yan An Road (West), Shanghai, 200040, China

中国上海市延安西路65号上海国际贵都大饭店办公楼 405 单元

Phone: +86-21-62489820

Fax: +86-21-62489821 
(C) 2012 The Author(s). Licensee IntechOpen. This is an open access article distributed under the terms of the Creative Commons Attribution 3.0 License, which permits unrestricted use, distribution, and reproduction in any medium, provided the original work is properly cited. 